International Journal of Engineering \& Technology, $7(4.33)(2018) 171-177$
International Journal of Engineering \& Technology
Website: $w w w . s c i e n c e p u b c o . c o m / i n d e x . p h p / I J E T$
Research paper

\title{
The Mapping of Vocational Competencies Based on Regional Potential Using Geographic Information System
}

\author{
Danny Meirawan ${ }^{1 *}$, Ana A ${ }^{2}$, Awindha Eko Lusiana ${ }^{3}$, Tutin Aryanti ${ }^{4}$ \\ ${ }^{1}$ Civil Engineering Education, Faculty of Technology and Vocational Education UPI, Indonesia \\ ${ }^{2}$ Home Economics Education, Vocational and Technology Education Faculty UPI, Indonesia \\ ${ }^{3}$ Vocational Education and Technology Study Program, Post Graduate UPI, Indonesia \\ ${ }^{4}$ Architecture Education, Vocational and Technology Education Faculty UPI, Indonesia \\ *Corresponding author E-mail: dmeirawan@upi.edu
}

\begin{abstract}
Regional potential based approach is one of the strategies to create quality human resources that can develop regional potential. Vocational competence which is not in line with the local potential has become a problem in one of regencies in Indonesia namely Tangerang Regency. The purpose of this study was to map vocational competencies in Tangerang Regency based on the potential using the Geographic Information System (GIS). GIS is used to help school mapping so that educational planning can be well realized. This research uses a qualitative approach with descriptive research methods. The data analysis uses LQ and PCA analysis. The results of the LQ analysis show that there are 10 districts that have industrial potential, 14 districts with livestock potential, 4 districts with fishery potential and 19 districts with agricultural potential. The results of the PCA analysis show that there are 14 districts which become priority locations for vocational school development. The mapping of vocational competencies which is based on regional potential in Tangerang Regency uses GIS in the form of maps of regional potential distribution and maps of priority locations for vocational school development.
\end{abstract}

Keywords: vocational competence; Tangerang Regency; regional potential; SIG.

\section{Introduction}

The quality of vocational school graduates in Indonesia has several problems such as the high unemployment rate of vocational school graduates due to the incompatibility between the competencies possessed by vocational school graduates and the competencies needed by the industry [15]. The expertise competencies available in Vocational Schools are opened if needed by the community and supported by the local potential [1]. Vocational problems do not only occur in Indonesia but also occur in Europe and Asia. The impact of this incompatibility is that the skills possessed by SMK graduates are not used and the salary are inappropriate [2].

The regional potential-based approach is expected to provide a real depiction of the workforce needs and can meet the workforce demand while also considering the established system and mechanism. The regional potential-based approach is also expected to prepare students to enter the workforce as productive laborers capable of creating competitive prime products [3].

Tangerang Regency is located in the eastern part of Banten Province and which consists of lowland and highland. It has potential natural resources to be developed, such as industry, livestock, fisheries and agriculture. Industrial potential is supported by its strategic location and easy access to the city. Industrial sector revenue in 2015 was 37.6 trillion Rupiah.

The potential of fisheries and agriculture cannot be utilized optimally. Many marine potentials produce marine fish are located along the north coast. There are 85,757 households which have agricultural businesses. Fish caught by fishermen and agricultural products are only sold as original ingredients. Even if it is pro- cessed, it only uses traditional processes without using technology so its economic value is limited. In the 70 s this area was known as the rice barn.

Regional potential can have more economic value if there are human resources who manage it well. Skilled and professional vocational graduates can become human resources who can develop regional potential. In Tangerang Regency, there are 172 Vocational Schools, 12 state status Vocational Schools and 160 private status Vocational Schools. The opening of vocational schools and expertise competencies is carried out based on the departments that are in demand by the community, not based on the needs of the community. Many vocational graduates are unemployed due to the availability of employment opportunities and are not relevant to their expertise competencies. Vocational graduates also tend to look for work in other areas. Conditions like this cause regional economic growth to be slow because of the lack of skilled workers that are relevant to the needs of the community and vocational graduates tend to choose to work in other areas [15].

The number and variety of schools in one European country rapidly increased in response to the government's policy agenda aimed at expanding the choice of provisions as a mechanism to raise educational standards [4]. This was done in addition to raising educational standards as well as helping prepare students for the world work to advance the nation's economic development [17]. In addition, there needs to be a large commitment from all stakeholders in realizing it [18]. The increasing number of students, teachers and schools at the vocational level and the potential of the schools they have owned are not well documented. Data collection has been carried out manually and has not been well integrated so that information and reporting needs are fast and accurate. School potential mapping is needed by the Tangerang District Education 
Office for strategic planning so that school development will be right on target and in accordance with school needs [5]. Application that can help this problem is the Geographic Information System (GIS). GIS is a kind of software that can be used to enter, store, manipulate and display geographic information along with its attributes [6] .

Along with the increasing population and the development of complex life, GIS must be further enhanced as an inventory of natural resources and human resources as well as providing information to the public easily [7]. The benefits of GIS are:

1. Knowing the distribution of various natural resources;

2. Knowing the distribution of residential areas, industrial zones, schools, hospitals, entertainment and recreation facilities and offices;

3. Reference to development planning so that construction can be planned and organized;

4. Knowing the potential and distribution of the population

5. For data collection and development of transportation networks;

6. Observing the weather and climate of an area.

GIS processes two kinds of data, namely spatial data (geospatial data) and non-passive data (attribute data).

1. Spatial Data (Geospatial Data)

Spatial data contains the location of an object on a map based on its geographical position above the earth using a coordinate system. Spatial data is represented in two models, vector models and raster models. The vector model is represented by symbols consist of interconnection lines and points that represent the location and boundary lines of geographic entities, including lines (lines), polylines (polygons), points (points), areas (regions) and nodes (cut points). The Raster model is produced from satellite and aerial photography technology, which presents geographic objects as grid or cell structures that are known as pixels.

2. Non-Financial Data (Attribute Data)

This data contains the characteristics or information of an object on a map that is not related to the geographical position of a particular object. For example, attribute data from a city are area population, population density, crime rate, and so on.

GIS will process spatial data and complete attribute data. The GIS processing process are: (1) Inputting data, this stage is to enter data and convert the original data into the desired format that can be received and used in GIS; (2) Analyzing data, the process of data in GIS includes calling, manipulating and analyzing data that has been stored on the computer. Data manipulation includes creating a new database, deleting new databases, creating database tables, filling and pasting data into tables, changing and editing data, and creating an index for each table or database; (3) Presenting data (data output), data that has been analyzed in GIS can provide information to users. Data can be presented in thematic maps, tables, graph reports, etc. [8].

The analysis in this study uses LQ for regional potential analysis and PCA for education analysis. The results of the LQ and PCA analysis can provide expertise competency recommendations that corresponds with regional potential and can provide an overview of priority locations for vocational school development. The results will be displayed in the GIS so as to facilitate transparent decision making so that people can appreciate various information related to public policy. Transparent decision is to prevent government officials from misusing power.

\section{Methodology}

This study uses qualitative approach because the problems discussed in this study are not related to numbers but to express, define and describe the mapping of vocational competencies in Tangerang Regency based on regional potential using GIS. GIS is a software that provides various functions to create, obtain, integrate, transform, visualize, analyze, model and prepare information about the surface of the earth [19]. The method used in this research is descriptive analysis method using LQ analysis and PCA analysis.

Location Quotient Analysis (LQ) is used to determine activity sector that drives economic growth in an area. LQ analysis compares the potential part of the region to a particular sector in a (local) region with a part of the potential area for the same sector in a larger area [16]. The LQ analysis formula mentioned in [9] study is:

$\mathrm{LQi}=\frac{S i / N i}{S / N}$

The value of LQ will show the capability of an area in a particular sector, if:

a. The value of $\mathrm{LQ}<1$, it means that the region has the tendency to import from other region

b. The value of $L Q=1$, it means that the region is able to selfprovide in a particular activity

c. The value of $L Q>1$, it means that the region has tendency to export to other region [9].

Principal Component Analysis (PCA) is one of multivariate analysis methods that has a high level of difficulty but can produce accurate data compared to other methods [9]. PCA analysis is used to determine the priority of vocational school development by considering educational indicators.

\section{Results and Discussion}

\subsection{Results}

Tangerang Regency is located in the eastern part of Banten Province. The total area is $1,110.38 \mathrm{Km} 2$ or $12.62 \%$ of the total area of Banten Province. Its northern border is: Java Sea; east: DKI Jakarta Province and Tangerang City; south: Bogor Regency and Depok City and west: Serang and Lebak Regencies. Tangerang Regency has four regional potentials i.e. industrial, livestock, agriculture and fisheries.

\subsection{Industrial Potential}

There are 493,056 people who work in the industrial sector and work at 4,883 companies in 27 districts. Districts that do not have company or enterprise are Mount Kaler and Sukadiri. Industrial potential is supported by the strategic location of Tangerang Regency. Tangerang Regency is very close to many strategic locations such as the capital city of Indonesia, the capital of Banten Province and the port of Merak and is supported by easy and adequate portfolios that facilitate export of manufactured goods. This strategic location can help improve the potential of the region. Strategic location can increase company revenue [11]. The results of research in Norway stated that airports have a positive impact on the development of a region and can create jobs [12]. Revenues from the industry reached 10.204 trillion. The amount of this income reflects the magnitude of the industrial potential owned by Tangerang Regency.

\subsection{Livestock Potential}

Tangerang Regency has vast vacant land to be used for livestock sector. Farm animals raised by households in Tangerang Regency are buffalo, horse, cow, pig, sheep, duck and chicken. The number of animals that are most breed are chickens as many as 17,853 , 9,996 sheep, 8,928 duck, 4,385 buffalo, 3,016 cow, 121 pig and 2 horses.

Factors which supported this potential are:

a. The selling price of poultry such as chickens and ducks is higher than other regions; 
b. There are many veterinarians and animal husbandry graduates in the structure of Department of Livestock Affairs so they can help run livestock activities;

c. Tangerang Regency with the City of Jakarta is connected by motorway (toll road) which can speed up the delivery time by 1.5 hours.

\subsection{Fishery Potential}

The fishery activities in Tangerang Regency include fishing and farming. These activities are carried out in the sea and public waters (swamps, lake, former sand excavation, rivers). Farming activities are carried out in ponds, basin, rice fields, japung and sea farming. The types of fishing gear used are bubu, drifting gill nets, fixed gill nets, fishing rods, sero and others and the most widely used are bubu. Of the 2,533 in 2013 it was 44,700 in 2014 and 2015.

Data from the Department of Fisheries and Maritime Affairs, Kab. Tangerang in 2015 said that the amount of fishery production reached 40,870.63 tons, more than half of which was produced from fishing in the sea and a quarter was produced from brackish water ponds. Fisheries potential produces income of Rp. 694,830,597.00. Fish species that are farmed are milkfish, mullet, tiger shrimp, white shrimp, fire-fire shrimp, mujair / tilapia, mas, pomfret, catfish, gurame, catfish, tawes, cork, siam, green mussel, nilem, krapu, vaname shrimp and seaweed. Table 1 describes the amount of fish production according to the farming place and the income produced.

Table 1: Fish Production According to Farming Sites in 2015

\begin{tabular}{|l|c|c|}
\hline \multicolumn{1}{|c|}{ Farming Site } & Prodction (Ton) & Value (Rupiah) \\
\hline I. Catching & & \\
\hline 1. Sea & $19.596,70$ & 512.894 .461 \\
2. Perairan Umum & 92,21 & \\
\hline II. Farming & & \\
1. Ponds & $10.563,60$ & 84.508 .800 \\
2. Basin & $4.814,72$ & 68.580 .800 \\
3. Japung & 440,10 & 4.729 .000 \\
4. Sea & $4.848,00$ & 9.696 .000 \\
\hline \multicolumn{1}{|c|}{ Total } & $40.870,63$ & 694.830 .597 \\
\hline
\end{tabular}

\subsection{Agriculture Potential}

Sub-sector of food includes: rice, corn, cassava, sweet potatoes, peanuts and vegetables (long beans, spinach, eggplant, cucumber, kale, mustard greens, spinach, cayenne and large chili). In 2015 Tangerang Regency's high productivity were rice, cassava and kale.

Rice productivity reached $60.31 \mathrm{Kw} / \mathrm{Ha}$ with a planting area of $53,727 \mathrm{Ha}$ and the amount of production reached 324,053 tons. Cassava commodity productivity reached $129.42 \mathrm{Kw} / \mathrm{Ha}$ with planted area of $162 \mathrm{Ha}$ and the amount of production was 2,096 tons. Kangkung commodity is $39.12 \mathrm{Kw} / \mathrm{Ha}$ with a planting area of 518 ha and the amount of production produced reaches 20,264 tons.

\subsection{Geographic Information System Display (GIS)}

GIS is software that functions primarily as a means of delivering information by using maps to speed up decision making. Users can search for desired information using GIS. Mapping Competencies of vocational schools which are based on regional potential can be utilized by users. Admin can add data easily if there is a change in Vocational information. GIS presents various features such as viewing the map of Tangerang Regency as well as other general information, potential areas in Tangerang Regency, maps of regional potential distribution, educational potential, school development and vocational data in Tangerang Regency [13].

After spatial and non-spatial data have been collected, data conversion to the creation and discussion of tables is carried out. The software used for data collection and processing is Postgre SQL and Quantum GIS, while for mapping using MapServer alongside
Chameleon and creating websites using PHP and Java scripts [7]. The procedure sequence of a program will be described in a flowchart. Flowcharts can help analysts and programmers to solve problems into smaller segments and help analyze other alternatives in operation. The main purpose of using a flowchart is to describe a simple, detailed, neat and clear stage of problem solving using standard symbols [14]. The GIS application flowchart can be seen in Appendix A.

\subsection{LQ Analysis}

The components needed to determine regional potential are business potential data or value added of a particular sector per district and per district. Potential areas analyzed are industrial potential, livestock, fisheries and agriculture. Weighting of values is done using LQ analysis. LQ analysis on industrial potential is carried out by dividing the number of industrial businesses in a district (Si) with the number of companies in a district (Ni), the results of this division will be compared with the number of businesses in all fields in a district (S) divided by the number of businesses all fields in a district $(\mathrm{N})$. The same way can be done to find out other potential.

Table 2: Regional Potential Analysis Results using LQ Calculation

\begin{tabular}{|c|c|c|c|c|c|}
\hline \multirow[b]{2}{*}{$\dot{\mathbf{z}}$} & \multirow[b]{2}{*}{ 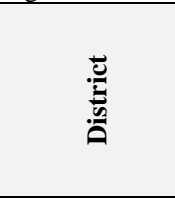 } & \multicolumn{4}{|c|}{ Potential } \\
\hline & & 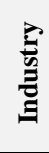 & 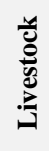 & $\frac{\vec{d}}{\bar{y}}$ & 光 \\
\hline 1 & Cisoka & - & $\sqrt{ }$ & - & $\sqrt{ }$ \\
\hline 2 & Solear & - & $\sqrt{ }$ & - & $\sqrt{ }$ \\
\hline 3 & Tigaraksa & $\sqrt{ }$ & $\sqrt{ }$ & - & $\sqrt{ }$ \\
\hline 4 & Jambe & - & $\sqrt{ }$ & - & $\sqrt{ }$ \\
\hline 5 & Cikupa & $\sqrt{ }$ & $\sqrt{ }$ & - & - \\
\hline 6 & Panongan & $\sqrt{ }$ & $\sqrt{ }$ & - & $\sqrt{ }$ \\
\hline 7 & Curug & $\sqrt{ }$ & $\sqrt{ }$ & - & - \\
\hline 8 & Kelapa Dua & $\sqrt{ }$ & $\sqrt{ }$ & - & - \\
\hline 9 & Legok & $\sqrt{ }$ & - & - & $\sqrt{ }$ \\
\hline 10 & Pagadengan & - & $\sqrt{ }$ & - & $\sqrt{ }$ \\
\hline 11 & Cisauk & - & $\sqrt{ }$ & - & $\sqrt{ }$ \\
\hline 12 & Pasar Kemis & $\sqrt{ }$ & - & - & $\sqrt{ }$ \\
\hline 13 & Sindang Jaya & - & $\sqrt{ }$ & - & $\sqrt{ }$ \\
\hline 14 & Balaraja & $\sqrt{ }$ & - & - & $\sqrt{ }$ \\
\hline 15 & Jayanti & - & - & - & $\sqrt{ }$ \\
\hline 16 & Sukamulya & - & - & - & $\sqrt{ }$ \\
\hline 17 & Kresek & - & - & - & $\sqrt{ }$ \\
\hline 18 & Gunung Kaler & - & - & - & $\sqrt{ }$ \\
\hline 19 & Kronjo & - & - & $\sqrt{ }$ & - \\
\hline 20 & Mekar Baru & - & - & - & $\sqrt{ }$ \\
\hline 21 & Mauk & - & - & $\sqrt{ }$ & - \\
\hline 22 & Kemiri & - & $\sqrt{ }$ & - & $\sqrt{ }$ \\
\hline 23 & Sukadiri & - & - & $\sqrt{ }$ & - \\
\hline 24 & Rajeg & - & $\sqrt{ }$ & - & $\sqrt{ }$ \\
\hline 25 & Sepatan & $\sqrt{ }$ & - & - & $\sqrt{ }$ \\
\hline 26 & Sepatan Timur & - & $\sqrt{ }$ & - & $\sqrt{ }$ \\
\hline 27 & Pakuhaji & - & - & $\sqrt{ }$ & - \\
\hline 28 & Teluknaga & - & $\sqrt{ }$ & - & - \\
\hline 29 & Kosambi & $\sqrt{ }$ & $\sqrt{ }$ & - & - \\
\hline
\end{tabular}

Base and non-base criteria can be determined from the LQ value per each regional potential. Districts or districts will have baseline criteria if their LQ value is more than one, meaning that the region or district has a tendency to export to other regions or districts and the area has the potential to be developed. The results of the LQ analysis are explained in Table 2 and the terms are attached to Appendix B.

\subsection{PCA Analysis}

PCA is a multivariate analysis method that can be calculated using XLSTAT Microsoft Excel 2013 software. The data needed to calculate the PCA data are: (a) The number of population aged 1519 years (X1); (b) Student ratios per school (X2); (c) Student ratio 
per class (X3); (d) Student ratio per teacher (X4); (e) Student ratio per new student (X5) and (f) Student ratio per APK (X6). The Kasara Partition Rate (APK) is calculated from the number of vocational students divided by the number of population aged 15 19 years and multiplied by 100 . PCA values are obtained by adding ins $\rightarrow$ XLSTAT $\rightarrow$ Analyzing data $\rightarrow$ Principal Componen Analysis $\rightarrow$ input data X1, X2, X3, X4, X5 and X6.

There are 15 districts whose PCA values are below the average i.e. Mekar Baru District (1132.64), Kemiri (1506.42), Jambe (1564.93), Kronjo (1574.77), Sukadiri (1637.10), Mount Kaler (1662.85), Sukamulya (1742,53), Krishna (1908,71), Cisauk $(2057,55)$, Jayanti $(2464,36)$, Solear $(2608,11)$, Mauk $(2638,11)$ Sindang Jaya (2666.04), Sepatan Timur (2754.79) and Cisoka (2917.53). Details of PCA calculations are explained in Appendix C. These districts are priority locations for the development of vocational schools. The development of vocational schools is by opening new skills competencies or by opening new vocational schools.

This study has six education indicators as variables. PCA analysis can be used for research which has more than one number of independent and dependent variables. PCA analysis has a screen plot to help determine the variables that most contribute to data variation [14]. Scree plot of PCA analysis results can be seen in Figure 1.

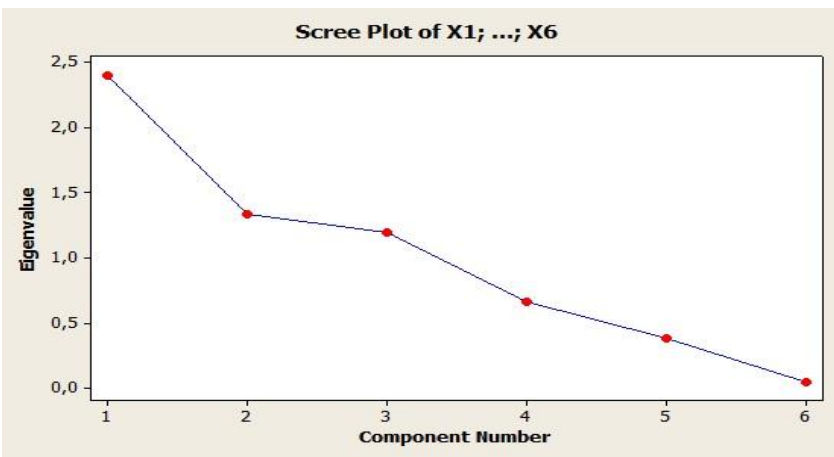

Fig. 1: Screen Plot the Result of PCA Analysis

The variables that contribute the most are those that have more than one component number. The most important educational indicators in this study were the population aged 15-19, student ratios per class and student ratios per teacher. Subsequent research with the same topic in determining education potential can reduce the number of indicators without losing information significantly.

\subsection{Discussion}

Tangerang Regency has 168 Vocational Schools, 12 are public and 156 are private. Management of Vocational Schools in Tangerang Regency until 2015 is based on Vocational Principal Data from the Directorate of Vocational High School Development, consisting of nine areas of expertise which can be seen in Appendix 6.

The ten most competencies of Vocational schools which can be found in Tangerang Regency are:

a. Computer Engineering and Information Technology: 96 Vocational Schools

b. Administration: 81 Vocational Schools

c. Automotive Engineering: 62 Vocational Schools

d. Finance: 53 Vocational Schools

e. Health: 19 Vocational Schools

f. Business Administration: 12 Vocational Schools

g. Mechanical Engineering: 11 Vocational Schools

h. Electric Power Engineering: 9 Vocational Schools

i. Electronic Engineering: 5 Vocational Schools

j. Building Engineering: 4 Vocational Schools

Analysis of expertise competencies needed based on the potential regional considerations owned by the district. Consideration in deciding the expertise competencies required is based on LQ and PCA analysis. It will be explained in Table 3.

Table 3: The Need of Expertise Competency in Vocational School Development Priority Locations

\begin{tabular}{|c|c|c|}
\hline District & $\begin{array}{c}\text { Regional } \\
\text { Potential }\end{array}$ & Expertise Study Program Needed \\
\hline Mekar Baru & Agriculture & Agribusiness dan agrotechnology \\
\hline Kemiri & Livestock & Agribusiness dan agrotechnology \\
\cline { 2 - 3 } & Agriculture & Agribusiness dan agrotechnology \\
\hline Jambe & Livestock & Agribusiness dan agrotechnology \\
\hline Kronjo & Fishery & Fisheries and Maritime \\
\hline Sukadiri & Fishery & Fisheries and Maritime \\
\hline Gunung Kaler & Agriculture & Agribusiness dan agrotechnology \\
\hline Sukamulya & Agriculture & Agribusiness dan agrotechnology \\
\hline Kresek & Agriculture & Agribusiness dan agrotechnology \\
\hline Cisauk & Livestock & Agribusiness dan agrotechnology \\
\hline Jayanti & Agriculture & Agribusiness dan agrotechnology \\
\hline Solear & Livestock & Agribusiness dan agrotechnology \\
\hline Sindang Jaya & Livestock & Agribusiness dan agrotechnology \\
\hline Sepatan Timur & Livestock & Agribusiness dan agrotechnology \\
\hline Cisoka & Livestock & Agribusiness dan agrotechnology \\
\cline { 2 - 3 } & Agriculture & Agribusiness dan agrotechnology \\
\hline
\end{tabular}

There are 15 districts which are the priority locations for the development of vocational schools. Vocational schools in Mauk district already have expertise competencies that support the regional potential. Fourteen other districts have regional potential that has not been supported by expertise competencies. Potential areas that have not been supported are agriculture and livestock. Agriculture can be supported by Agribusiness and Agrotechnology expertise study programs and the field of livestock can be supported by Agriculture and Marine expertise study programs.

Agribusiness and Agrotechnology expertise study programs has eight competency skills that need to be developed, i.e.: (1) Crop Production Agribusiness; (2) Agricultural Counseling; (3) Livestock Production Agribusiness; (4) Agricultural Product Agribusiness; (5) Aquatic Product Agribusiness; (6) Agricultural Mechanisms; (7) Animal Health; and (8) Agricultural and Forestry Product Processing Agribusiness.

There are three competencies in the expertise of the Agriculture and Marine expertise study program that need to be developed namely (1) Fish-catching Technology; (2) Technology and Production of Fisheries and Farming; and (3) Sailing.

\section{Conclusion}

The results of the LQ and PCA analysis as well as the discussion of the data are displayed in GIS Chapter IV can be concluded as follows:

1. The results of the LQ analysis show that there are 10 districts that have industrial potential, 16 districts with livestock potential, 4 districts with fishery potential and 20 districts with agricultural potential;

2. There are 35 competencies found in Vocational High Schools in Tangerang which are spread in 29 districts. Vocational competencies found in Mauk and Sepatan districts are in accordance with the potential of the local area. Vocational competencies in 27 other districts have not fully supported the potential of the local area. The expertise study program based on the regional potential needed for 19 districts which have agricultural potential, namely Agribusiness and Agrotechnology which can be developed into eight competencies. The expertise study program is based on the regional potential needed for 23 districts which have agricultural and fishery potential such as Agriculture and Marine which can be developed into three competencies;

3. Mapping of vocational competencies in Tangerang Regency is based on regional potential by using GIS in the form of maps of regional potential distribution and maps of priority locations for vocational school development. Other research results are also displayed in GIS. GIS display includes data from 
Tangerang Regency Vocational School which consists of the date of vocational school standing, location of Vocational School, number of students, competence possessed by Vocational School, regional potential owned by the district where vocational schools stand and recommendations for vocational competencies in accordance with regional potential.

\section{References}

[1] Nurharjadmo, W. (2008). Evaluation of implementation of dual system education policies in vocational schools. Spirit Publik, 4(2), 215-228.

[2] Béduwé, C., \& Giret, J. (2011). Mismatch of vocational graduates: What penalty on french labour market? Journal of Vocational Behavior, 78(1), 68-79.

[3] Sundar, A., \& Sulistiowati, R. (2010). Decentralization of education in the era of regional autonomy (study of school-based education in SMK 1 pesisir tengah district of West Lampung). Jurnal Ilmiah Administrasi Publik Dan Pembangunan, 2(1), 225-236.

[4] Courtney, S. J. (2015). Mapping school types in England. Journal of Educational Administration and History, 47(3), 799-818.

[5] Kharistiani, E., \& Aribowo, E. (2013). Geographic information system mapping potential of WEB-based high school / vocational high school (Case study: Kebumen Regency). Jurnal Sarjana Teknik Informatika, 1(1), 712-720.

[6] Prahasta, E. (2005). Basic concepts of geographic information systems. Penerbit Informatika.

[7] Masykur, F. (2014). Geographic information system implementation using Google Maps API in student mapping. Jurnal SIMETRIS $5(2), 181-186$

[8] Umar, H. (2006). Marketing research and consumer behavior. PT. Gramedia Pustaka Utama.

[9] Morrissey, K. (2014). Producing regional production multipliers for Irish marine sector policy: A location quotient approach. Ocean and Coastal Management, 91, 58-64.
[10] Bodroža-solarov, M., Kljajić, P., Andrić, G., Filipčev, B., Šimurina, O., Golić, M. P., \& Adamović, M. (2011). Application of principal component analysis in assessment of relation between the parameters of technological quality of wheat grains treated with inert dusts against rice weevil (Sitophilus oryzae L.). Scientific Journal "Pesticides and Phytomedicine," 26(4), 385-390.

[11] Rangkuti, F. (2006). SWOT analysis technique to dissect business case: Reorientation of strategic planning concept to face the 21st century. PT. Gramedia Pustaka Utama.

[12] Tveter, E. (2017). Research in transportation economics the effect of airports on regional development: Evidence from the construction of regional airports in Norway. Research in Transportation Economics, 30(1), 1-9.

[13] Muljo, B., \& Susilowati, D. (2003). Application of remote sensing methods and geographic information systems for change analysis (Case study: Kali Surabaya region). Makara Teknologi, 7(1), 1-9.

[14] Ahyani, I. A., Suprayogi, A., \& Awaluddin, M. (2013). Geographic Information System Application (GIS) for inventory of education facilities and infrastructure using Google MAPS API (Case study: Kaliwungu district, Kendal district). Jurnal Geodesi Undip, 2(2), 95-102.

[15] Jatmoko, D. (2013). Relevance of light vehicle engineering skills competency curriculum to the needs of the industrial world in Sleman Regency. Jurnal Pendidikan Vokasi, 3(1), 1-13.

[16] Budiharso, S. (2001). Analysis techniques for the development of coastal and marine areas. Pradnya Paramita.

[17] Venansius, B., \& Wilfred, K. N. (2014). The role of TVET building regional economies. International Journal of Vocational Education Training, 22(1), 7-15.

[18] Margarita, P. (2016). Regional overview: What is the government's role in greening TVET? TVET Online Issue, 6, 1-18.

[19] Michael, F. G. (2016). Geographic information system. Sage Publication.

\section{Appendix A}

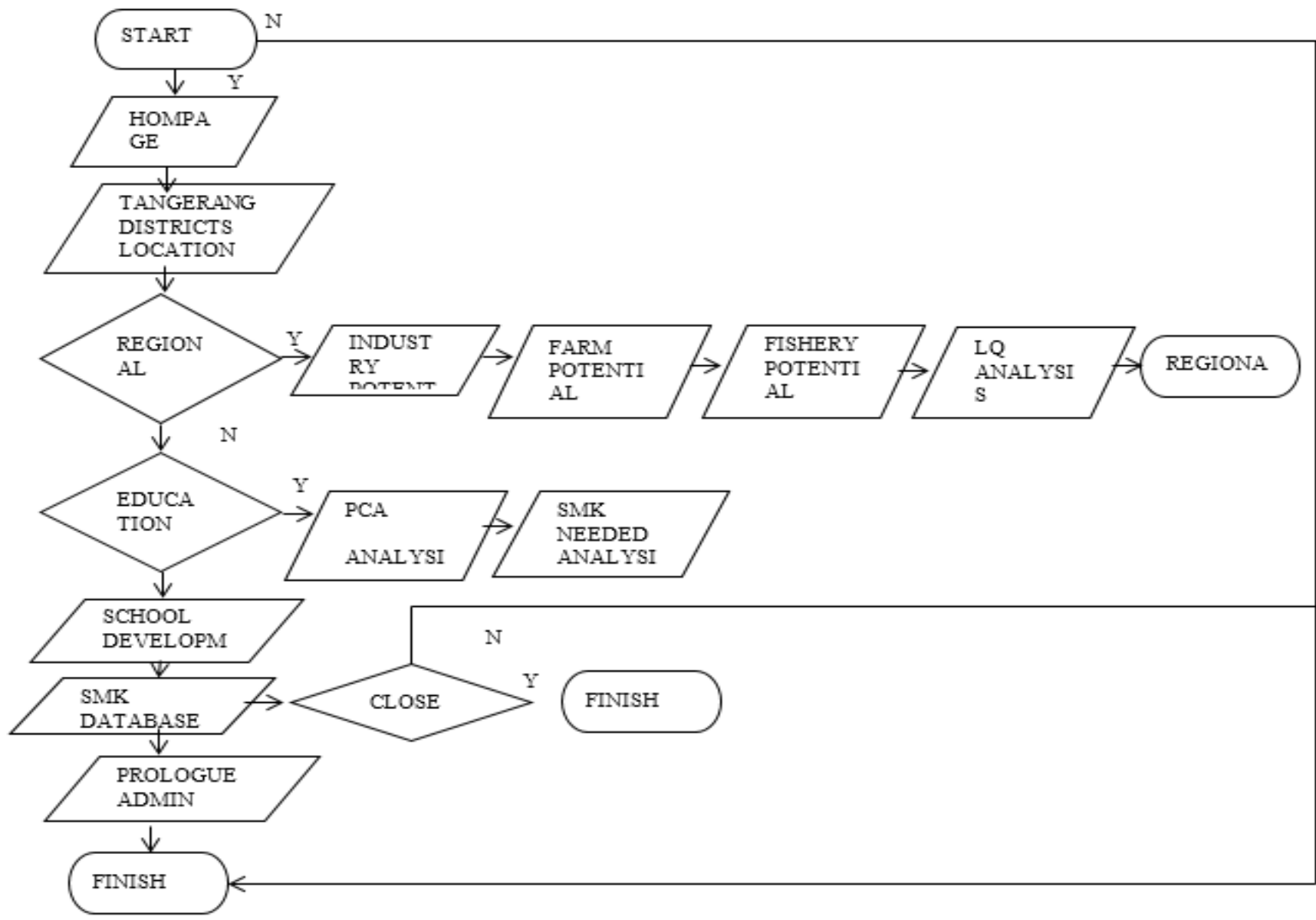

Fig. 1: Flowchart of SIG 


\section{Appendix B}

Agricultural Production Table of Tangerang Regency

\begin{tabular}{|c|c|c|c|c|c|c|c|c|c|c|c|c|c|c|c|c|}
\hline \multirow[b]{2}{*}{$\begin{array}{l}\text { N } \\
\text { o. }\end{array}$} & \multirow[b]{2}{*}{ District } & \multicolumn{15}{|c|}{ Type of Vegetable (Ton) } \\
\hline & & Rice & $\begin{array}{l}\text { Cor } \\
n\end{array}$ & $\begin{array}{l}\text { Cas- } \\
\text { sava }\end{array}$ & $\begin{array}{l}\text { Swe } \\
\text { et } \\
\text { Po- } \\
\text { tato }\end{array}$ & $\begin{array}{l}\text { Grou } \\
\text { nd } \\
\text { Nut }\end{array}$ & $\begin{array}{l}\text { Lon } \\
\text { g } \\
\text { Bea } \\
\text { ns } \\
\end{array}$ & $\begin{array}{l}\text { Spin- } \\
\text { ach }\end{array}$ & $\begin{array}{l}\text { Auber- } \\
\text { gine }\end{array}$ & $\begin{array}{l}\mathrm{Cu}- \\
\text { cumber }\end{array}$ & $\begin{array}{l}\text { Wa- } \\
\text { ter } \\
\text { Spin- } \\
\text { ach }\end{array}$ & Sawi & $\begin{array}{l}\text { Shal- } \\
\text { lot }\end{array}$ & $\begin{array}{l}\text { Cay- } \\
\text { enne }\end{array}$ & $\begin{array}{l}\text { Chi } \\
\text { lli }\end{array}$ & Total \\
\hline 1 & Cisoka & $\begin{array}{l}1163 \\
9\end{array}$ & 0 & 208 & 24 & 4 & 8,2 & 0 & 0 & 6,9 & 0 & 0 & 0 & 0 & 0 & 11890 \\
\hline 2 & Solear & 9878 & 0 & 130 & 19 & 17 & 17,9 & 0 & 0 & 12,9 & 0 & 0 & 0 & 0 & 0 & 10075 \\
\hline 3 & Tigaraksa & 9003 & 18 & 91 & 10 & 0 & 4,7 & 0 & 0 & 7,6 & 0 & 0 & 0 & 0 & 0 & 9134 \\
\hline 4 & Jambe & 4859 & 30 & 181 & 0 & 17 & 6 & 0 & 0 & 0 & 0 & 0 & 0 & 0 & 2,8 & 5096 \\
\hline 5 & Cikupa & 2814 & 0 & 78 & 0 & 0 & 5,8 & 0 & 0 & 14,8 & 0 & 0 & 0 & 0 & 0 & 2913 \\
\hline 6 & Panongan & 5791 & 3 & 131 & 0 & 0 & 7,7 & 0 & 0 & 7,8 & 0 & 0 & 0 & 0 & 0 & 5941 \\
\hline 7 & Curug & 1685 & 21 & 273 & 87 & 19 & 9,9 & 1,8 & 0 & 8,6 & 3,2 & 0 & 0 & 0 & 0 & 2109 \\
\hline 8 & $\begin{array}{l}\text { Kelapa } \\
\text { Dua }\end{array}$ & 306 & 0 & 13 & 29 & 2 & 5,1 & 5,7 & 3,7 & 0 & 6,2 & 14,4 & 0 & 0 & 0 & 385 \\
\hline 9 & Legok & 8054 & 0 & 115 & 29 & 11 & 38 & 40,5 & 28 & 78,9 & 35,2 & 0 & 0 & 0 & 0 & 8430 \\
\hline 10 & $\begin{array}{l}\text { Pa- } \\
\text { gadengan }\end{array}$ & 6220 & 36 & 490 & 135 & 10 & 1,5 & 17,6 & 0 & 7 & 14 & 0 & 0 & 0 & 14 & 6945 \\
\hline 11 & Cisauk & 1912 & 32 & 155 & 78 & 0 & 3,7 & 35 & 3,5 & 3 & 40,5 & 0 & 0 & 4,1 & 5,5 & 2272 \\
\hline 12 & $\begin{array}{l}\text { Pasar } \\
\text { Kemis }\end{array}$ & 7410 & 0 & 0 & 0 & 0 & 2 & 7 & 8,3 & 0,2 & 6,5 & 4,5 & 0 & 0 & 0 & 7439 \\
\hline 13 & $\begin{array}{l}\text { Sindang } \\
\text { Jaya }\end{array}$ & 8888 & 24 & 51 & 10 & 0 & 11,5 & 0 & 0 & 26 & 0 & 0 & 0 & 0 & 0 & 9011 \\
\hline 14 & Balaraja & $\begin{array}{l}1060 \\
6 \\
\end{array}$ & 6 & 38 & 0 & 5 & 20,8 & 0 & 0 & 11,5 & 0 & 0 & 10,5 & 0 & 0 & 10698 \\
\hline 15 & Jayanti & $\begin{array}{l}1031 \\
7\end{array}$ & 12 & 13 & 19 & 2 & 3,9 & 0 & 0 & 13,4 & 0 & 0 & 0 & 0 & 0 & 10380 \\
\hline 16 & $\begin{array}{l}\text { Sukamul- } \\
\text { ya }\end{array}$ & $\begin{array}{l}1414 \\
8 \\
\end{array}$ & 0 & 0 & 0 & 0 & 19,9 & 0 & 0 & 18,7 & 0 & 0 & 0 & 0 & 0 & 14187 \\
\hline 17 & Kresek & $\begin{array}{l}1373 \\
1 \\
\end{array}$ & 0 & 0 & 0 & 0 & 6 & 0 & 0 & 10,7 & 0 & 0 & 0 & 0 & 0 & 13748 \\
\hline 18 & $\begin{array}{l}\text { Gunung } \\
\text { Kaler }\end{array}$ & $\begin{array}{l}1670 \\
7\end{array}$ & 0 & 0 & 0 & 0 & 21,3 & 0 & 0 & 25,1 & 0 & 0 & 0,9 & 0 & 0 & 16754 \\
\hline 19 & Kronjo & $\begin{array}{l}1603 \\
7 \\
\end{array}$ & 0 & 13 & 0 & 2 & 38,9 & 0 & 0 & 129,7 & 0 & 0 & 0 & 0 & 4 & 16225 \\
\hline 20 & $\begin{array}{l}\text { Mekar } \\
\text { Baru }\end{array}$ & $\begin{array}{l}1315 \\
9\end{array}$ & 0 & 0 & 0 & 0 & 2,8 & 0 & 0 & 1,8 & 0 & 0 & 0 & 0 & 0 & 13164 \\
\hline 21 & Mauk & $\begin{array}{l}2610 \\
9 \\
\end{array}$ & 0 & 0 & 0 & 0 & 4,5 & 0 & 13,3 & 1,7 & 0 & 0 & 0 & 0 & 0 & 26129 \\
\hline 22 & Kemiri & $\begin{array}{l}1117 \\
0\end{array}$ & 0 & 0 & 0 & 0 & 20,6 & 0 & 0 & 78,3 & 0 & 0 & 0 & 0 & 0 & 11269 \\
\hline 23 & Sukadiri & $\begin{array}{l}2148 \\
2\end{array}$ & 0 & 0 & 0 & 0 & 15 & 39,5 & 0 & 218 & 38,7 & 45,2 & 0 & 0 & 0 & 21838 \\
\hline 24 & Rajeg & $\begin{array}{l}2481 \\
0 \\
\end{array}$ & 6 & 116 & 39 & 3 & $\begin{array}{l}272, \\
2 \\
\end{array}$ & 18 & 39,5 & 397,5 & 54 & 1 & 15 & 24,7 & 0 & 25796 \\
\hline 25 & Sepatan & 8447 & 0 & 0 & 0 & 0 & 1,5 & 69,7 & 4,5 & 3,3 & 68,9 & 33,2 & 0 & 0 & 0 & 8628 \\
\hline 26 & $\begin{array}{l}\text { Sepatan } \\
\text { Timur }\end{array}$ & $\begin{array}{l}1180 \\
5\end{array}$ & 0 & 0 & 0 & 0 & 0 & 444 & 0 & 0,2 & 475,9 & $\begin{array}{l}428, \\
5\end{array}$ & 0 & 0 & 0 & 13154 \\
\hline 27 & Pakuhaji & $\begin{array}{l}3526 \\
0 \\
\end{array}$ & 0 & 0 & 0 & 0 & $\begin{array}{l}119, \\
1 \\
\end{array}$ & 160,2 & 0 & 128,8 & 180,2 & 0 & 0 & 0 & 0 & 35848 \\
\hline 28 & Teluknaga & 9408 & 0 & 0 & 0 & 0 & 13,3 & $\begin{array}{l}1013, \\
4\end{array}$ & 13,1 & 75,6 & 960,9 & $\begin{array}{l}436, \\
9\end{array}$ & 0 & 0 & 0 & 11921 \\
\hline 29 & Kosambi & 2398 & 0 & 0 & 0 & 0 & 37,8 & 116,8 & 18,2 & 15,1 & 142,2 & 128 & 0 & 0 & 0 & 2856 \\
\hline Tot & & $\begin{array}{l}3240 \\
53\end{array}$ & 188 & 2096 & 479 & 92 & $\begin{array}{l}719, \\
6\end{array}$ & $\begin{array}{l}1969, \\
2\end{array}$ & 132,1 & 1303,1 & $\begin{array}{l}2026, \\
4\end{array}$ & $\begin{array}{l}1091 \\
, 7\end{array}$ & 26,4 & 28,8 & $\begin{array}{l}26, \\
3\end{array}$ & $\begin{array}{l}33423 \\
1,6\end{array}$ \\
\hline
\end{tabular}

Source: Statistic Center Tangerang Regency, 2015Appendix C

Table of Analysis of Educational Potential Results using PCA Calculation

\begin{tabular}{|c|c|c|c|c|c|c|c|c|}
\hline \multirow[b]{2}{*}{ No. } & \multirow[b]{2}{*}{ District } & \multirow[b]{2}{*}{$\begin{array}{c}\text { Population Age } \\
15-19(\mathrm{X} 1)\end{array}$} & \multicolumn{5}{|c|}{ Student Ratio Per } & \multirow[t]{2}{*}{ PCA Value } \\
\hline & & & $\begin{array}{l}\text { School } \\
(\mathrm{X} 2)\end{array}$ & $\begin{array}{l}\text { Classroom } \\
\text { (X3) }\end{array}$ & $\begin{array}{l}\text { Teacher } \\
\text { (X4) }\end{array}$ & $\begin{array}{c}\% \text { New } \\
\text { Student (X5) }\end{array}$ & $\begin{array}{l}\text { APK } \\
\text { (X6) }\end{array}$ & \\
\hline 1 & Cisoka & 9.364 & 547,75 & 54,78 & 35,34 & 34,37 & 23,40 & 2917,53 \\
\hline 2 & Solear & 8.661 & 471,75 & 40,15 & 24,83 & 31,48 & 21,79 & 2608,11 \\
\hline 3 & Tigaraksa & 13.422 & 338,83 & 41,49 & 33,06 & 35,56 & 30,29 & 3911,84 \\
\hline 4 & Jambe & 4.330 & 765 & 33,26 & 28,33 & 39,22 & 35,33 & 1564,93 \\
\hline 5 & Cikupa & 21.410 & 461,3 & 44,36 & 36,32 & 35,62 & 21,55 & 6118,58 \\
\hline 6 & Panongan & 11.006 & 602,5 & 42,28 & 31,71 & 32,99 & 43,79 & 3358,49 \\
\hline 7 & Curug & 17.018 & 387 & 39,58 & 26,79 & 34,14 & 20,47 & 4870,33 \\
\hline 8 & Kelapa Dua & 20.987 & 348,11 & 35,6 & 27,24 & 35,33 & 14,93 & 5934,44 \\
\hline 9 & Legok & 11.077 & 505,29 & 50,53 & 31,3 & 36,36 & 31,93 & 3344,12 \\
\hline 10 & Pagadengan & 10.532 & 887 & 44,35 & 28,61 & 37,43 & 8,42 & 3276,57 \\
\hline 11 & Cisauk & 7.224 & 170 & 27,2 & 15,81 & 36,18 & 9,41 & 2057,55 \\
\hline 12 & Pasar Kemis & 23.657 & 179,92 & 23,73 & 23,73 & 30,34 & 9,13 & 6555,37 \\
\hline
\end{tabular}




\begin{tabular}{|c|c|c|c|c|c|c|c|c|}
\hline 13 & Sindang Jaya & 9.170 & 353 & 27,15 & 27,15 & 47,31 & 3,85 & 2666,04 \\
\hline 14 & Balaraja & 10.655 & 442,44 & 46,3 & 29,94 & 32,70 & 37,37 & 3180,86 \\
\hline 15 & Jayanti & 8.596 & 197,43 & 43,19 & 25,59 & 32,05 & 16,08 & 2464,36 \\
\hline 16 & Sukamulya & 6.043 & 163 & 28,76 & 18,45 & 24,54 & 16,18 & 1742,52 \\
\hline 17 & Kresek & 6.528 & 217 & 47,17 & 30,14 & 39,35 & 16,62 & 1908,71 \\
\hline 18 & Gunung Kaler & 5.412 & 345,75 & 43,22 & 27,66 & 30,59 & 25,55 & 1662,85 \\
\hline 19 & Kronjo & 5.605 & 89 & 89 & 44,5 & 44,94 & 1,59 & 1574,77 \\
\hline 20 & Mekar Baru & 3.778 & 186,33 & 69,88 & 24,3 & 33,99 & 14,80 & 1132,64 \\
\hline 21 & Mauk & 8.262 & 776,33 & 48,52 & 27,73 & 39,24 & 28,19 & 2638,11 \\
\hline 22 & Kemiri & 4.823 & 259,29 & 72,6 & 27,92 & 39,28 & 37,63 & 1506,42 \\
\hline 23 & Sukadiri & 5.611 & 197 & 22,51 & 13,59 & 36,80 & 14,04 & 1637,10 \\
\hline 24 & Rajeg & 15.894 & 282,73 & 45,74 & 23,56 & 31,96 & 19,57 & 4511,80 \\
\hline 25 & Sepatan & 11.156 & 503 & 40,39 & 29,59 & 36,38 & 49,60 & 3376,28 \\
\hline 26 & Sepatan Timur & 10.038 & 41 & 13,67 & 20,5 & 39,02 & 0,41 & 2754,79 \\
\hline 27 & Pakuhaji & 11.706 & 346 & 74,14 & 49,43 & 41,23 & 8,87 & 3378,18 \\
\hline 28 & Teluknaga & 15.708 & 355,1 & 37,38 & 23,83 & 31,23 & 22,61 & 4488,96 \\
\hline 29 & Kosambi & 14.644 & 326 & 97,8 & 37,62 & 38,14 & 6,68 & 4155,65 \\
\hline
\end{tabular}

Source: http://niep.data.kemdikbud.go.id, 2017 